\title{
Colloid Nodule
}

National Cancer Institute

\section{Source}

National Cancer Institute. Colloid Nodule. NCI Thesaurus. Code C97056.

A non-cancerous thyroid gland nodule that contains colloid material. 